DOI: https://doi.org/10.31933/dijms.v2i4

Received: 25 January 2021, Revised: 7 March 2021, Publish: 15 March 2021

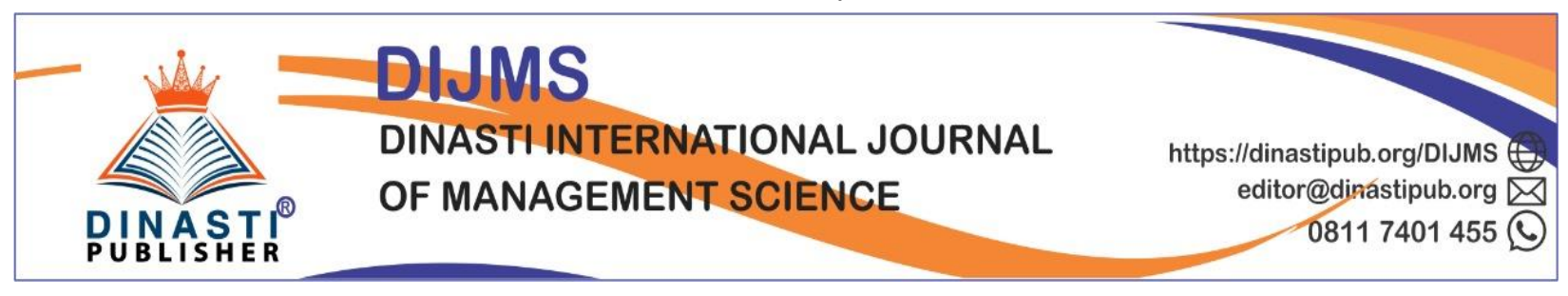

\title{
THE INFLUENCES OF ORGANIZATIONAL CULTURE, QUALITY OF WORK LIFE AND ORGANIZATIONAL COMMITMENT ON EMPLOYEE PERFORMANCE AT RSPAD GATOT SOEBROTO HOSPITAL
}

\author{
Nur Aktif Budiono \\ Universitas Negeri Jakarta, Jakarta, Indonesia, nuraktifb@yahoo.com, nuraktif123@gmail.com
}

Corresponding Author: Nur Aktif Budiono

\begin{abstract}
This research has purposed to revealed the influences of organizational culture, quality of work life and employee organizational commitment towards employee performance at RSPAD Gatot Soebroto Hospital. The survey type which conducted in this research where all the data obtained would be analyzed through path analysis after all these variables were put into correlation matrix. In this research, the RSPAD Gatot Soebroto Hospital workers will be chosen as unit analysis and 275 samples will be selected by stratified random sampling. This analysis result would be advantageous for the hospital's management, scientists and customers or patients. Through this research, it is known that any change or difference occurring in employee performance might be caused by organizational culture, quality of work life and organizational commitment. In conclusion, organizational culture, quality of work life and organizational commitment had an impact on employee performance. Thus, the policies regarding the factors of organizational culture, quality of work life and organizational commitment need to be arranged into strategic plan of human resources management.
\end{abstract}

Keywords: Organizational culture, quality of work life, employee organizational commitment and employee performance.

\section{INTRODUCTION}

One of the agencies that engaged in community service which needs to prioritize the principles of good management is the hospital. The hospital agency is an institution which implemented a high level of science and technology as well as professional human resources in the field of hospital services. Besides, hospitals should be able to compete in order to survive and win the competition so that it still exists, particularly now the demands of consumers/ patients for quality goods and services are getting higher, then besides the facilities and infrastructure that should be prioritized, the human resources (HR) are no less important. It should be expertise because no matter how sophisticated medical equipment is, if it is not handled by professional human resources with professional experience, it will be worthless, as the wise word said "The man behind the gun" means if the weapon depends on 
the person behind it. So high quality human resources are a very critical thing in the hospital service system as a whole.

Performance is the appearance of a person's work in the form of quality or quantity in an organization and performance could be form of an individual or employee's work group. Three important things in performance are purpose, range and assessment. Determining the goals of each organizational unit is a strategy to improve performance. This goal will provide direction and impact on how the organization's were expected work behavior from each employee. But the goals are not enough, therefore it is necessary to measure whether an employee has achieved the expected performance or not. For this cause, quantitative and qualitative assessment of performance standards of each employee's job and position plays a very important role. The final part of the performance process is the performance assessment itself which is linked to the process of achieving the goals.

According to Gibson's opinion, Ivancevich \& Donnally (2012:19) underline that performance is the level of success in carrying out the tasks and the ability to achieve predetermined goals. So the performance itself refers to the level of achievement of the employee or organization in carrying out tasks based on the required performance standards. Armstrong \& Taylor (2014:331) explained if the overall goal of performance management is to build a high-performance culture, where individuals and teams are responsible for the continuous improvement of business processes and skills, as well as contributing to a structure which prepares effective leadership. The ultimate goal is to focus on doing the right thing by achieving clear visions.

In the perspective which is described by Mondy \& Martocchio (2016:187) it is underlined if the performance in context of management is dynamic and continuous process. Every individual in the organization is a part of the performance management system. Every component in the system was integrated to ensure continuous organizational effectiveness.

In modern organizations, performance assessment is an important instrument for management to identify the goals and standards of individual performance within a certain time. Performance assessment forms the basis for decision making which affects salaries, promotions, dismissal, organizational commitment and other employment conditions. Ricky W. Griffin, Gregory Moorhead (2014:155) explained that the performance assessment of an employee is carried out in 3 (three) ways, such as evaluating and making comparisons with the work standards set by the organization to find out how much employee work behavior, documenting work results and informing the results of the job assessment to the employee.

According to Hersey et. al. (2012:386), the implementation of performance will be greatly influenced by factors within the employee themselves such as abilities or competencies and those from the organization such as how well leaders empower their workers, recognition and how leaders help advance their work performance abilities.

Donnelly et al. (2012:56) provide a more detailed and comprehensive picture of the factors which affect the performance, such as: (1) Individual variables, including abilities, skills, mental physical, family background, social level, experience, demographics (age, origin, gender). (2) Organizational variables, such as resources, leadership, rewards, work design structure. (3) Psychological variables include perceptions, attitudes, personality, learning and motivation. This opinion describes the things which could form or influence a person's performance. The individual factors with their unique psychological characteristics as well as organizational factors interact in a process that creates a quality of performance performed by a person in carrying out their roles and duties in the organization. 
Other things in an organization which could advance more than other organizations though the organization was engaged in the same field. This is because the organization has a unique organizational culture which is different, among others, in the norms and values, beliefs, philosophies of its members and the behaviour which is applied in the organization. Organizational culture could become the identity or character of the organization and as an organizational pride, so it needs to be retained and maintained as well as possible. The identity or character of an organization is a reference of each individual involved in the organization to uphold, then it would be able to have a positive influence on the organization in carrying out its activities and its performance well.

According to Schen (2010:7) culture is an abstraction, but the power which is created in the dynamics of social and organizational situations that occur in everyday life comes from a strong culture. If we don't understand how to manage this cultural power, then we become victims of culture. The power of culture is so strong because culture occurs outside of our consciousness. We need to understand culture not only the power of culture itself, but also culture helps explain many life experiences which might confuse and frustrate us sometimes in our social interactions and life in organizations. Most importantly, understanding the power of culture allows us to understand ourselves better.

Hofstede's (2011:3) was fully stated on Schen's cultural perspective which saying "culture is the collective programming of the mind which distinguishes the members of one group or category of people from others." According to Hofstede, this is always a series of phenomena collective, but could relate to different collective phenomena. Culture formed like a bell curve when a person moves from one society to others. Therefore, culture is said to be a program which is always moving and differentiate between one group to others.

In the context of organizational practical management, culture is a central issue concerned about organizational life on how people in organizations think, feel, value and act as a guideline to create an idea which has meaning and trust in social interactions in organizations. Mats Alvesson (2013:1) explained that when talking about culture, we usually think about someone sharing something, whether this division refers to a tradition which usually done and the way thinking or system of meanings or basic assumptions which set other people in certain direction. In various cultural research which carried out over the last thirty years, in a wide research about organization, the definitions of organizational culture have been produced and most of these definitions are connected to some form of sharing of meaning, interpretation, values and norms.

The achievement of any organization are depend on how to attract, recruit, motivate and retain a high performing workforce. Describing the factors which affect employee performance remains an essential question for human resource management practitioners. Employee performance depends not only on the amount of effort exerted, but also interventions which have an impact on other factors such as a person's abilities and traits, just like perceptions of their role in the company/agency.

Organizational factors and employee roles have an impact on employee performance. Including the work environment quality, abilities, effort, motivation, attitudes, personality, competence and job satisfaction. A successful organization considers job satisfaction from its employees as a satisfying factor which could improve the work performance.

Muindy and Peter (2015:225) were underlined if the quality of work life is important for organizations to continue to attract and retain the employees. Thus, the quality of work life has become an important part of the organization in the last 2 (two) decades due to the 
increasing demands of today's business environment. Quality of work life is beneficial for the conditions and environment in the workplace which supporting and promoting employee satisfaction by providing job safety and rewards.

On the other hand, Muindy and Peter $(2015: 226)$ stated if there are 8 (eight) major conceptual categories related to the quality of work life, such as: (1) fair and adequate compensation; (2) healthy and safe working environment and conditions; (3) direct opportunities to use and develop human capacities; (4) the opportunities for personal growth and security; (5) social integration in work organizations; (6) socially responsible organizations; (7) work space and privacy guarantees; and (8) the importance of the social environment in working life. This pattern was confirmed if the quality of working life is a function related to the value of the income and educational background of employees, where the higher income and education levels lead to a high quality of work life.

The starting point of success in managing an organization was determined by the success of management in controlling the potential and capabilities of human resources. Portrait of human resource management capabilities, which is the commitment dimension building implemented by the company, is an indicator of the company's success in creating a good resource system. In this case, the strength of employee commitment as a strong organizational commitment.

The level of employee commitment to the organization greatly influence by the performance that achieved both individually and the organization or company. Employee commitment is very crucial and significant impact. Even in some organizations which are firm enough to include the element of commitment to be the main requirement at the level of the position offered in each employee recruitment.

The achievement of an organization is greatly determined by how much employee involvement in commitment to the organization or organizational commitment in where they work. This commitment is seen as a strength within the person that binds them to carry out the job duties responsibly for the benefit of their organization. Commitment is a condition in which an individual sides with the organization with goals and desires to maintain their membership in the organization.

Robbins \& Judge (2013:75) stated if the organizational commitment is the level of an employee identifies with a particular organization and its goals and wishes to maintain membership in the organization. Luthans (2011:147) also suggests a similar definition, stating as follows: Organizational commitment is a strong desire to remain as a member in particular organization; a willingness to exert high levels of effort on behalf of the organization, and a definite belief in and acceptance of, the values and goals of the organization. Armstrong \& Taylor (2012:345) say that commitment refers to attachment and loyalty. It is associated with the feelings of individuals about their organization". Meanwhile, according to Mathis \& Jackson (2013:158) stated if the organizational commitment is the level of which employees belief and accept organizational goals and desire to remain with the organization.

Some of the opinions above underline if the organizational commitment is a condition in which employees side with certain organizations and their goals, as well as their desire to maintain their membership in the organization. Thus organizational commitment is the attachment of organizational members to the organization which establish and maintained on the basis of their willingness to give and receive competitive advantages from both parties. Organizational commitment includes by these 3 (three) attitudes, namely: (1) alignments with 
organizational goals; (2) feeling of involvement in organizational tasks; and (3) feelings of loyalty to the organization. Thus, organizational commitment besides could be defines as taking sides and involvement with the organization and also implies an emotional bond between employees and their organizations.

Besides the attitude of organizational commitment, Hunt, Osborn \& Uhl-Ben (2014:72) stated that there are 2 (two) main dimensions of organizational commitment, namely; (1) rational commitment, which reflects the feeling that work services related to financial, professional development and interest, (2) emotional commitment, which reflects important things, has real value and benefits for all employees. In essence, a strong emotional commitment to the organization, based on the values and interests of each other, is four times more likely to positively affect the performance than rational commitment, which is based on salary and self-interest.

Organizational commitment as stated by Meyer was confirmed the research that written by Allen and Meyer in 1990, that there are 3 (three) organizational components, such as (1) affective commitment; (2) continuance commitment; (3) normative commitment.

\section{RESEARCH METHODS}

This research is an associate with quantitative research that conducted through questionnaire then the results will be examined by path analysis. The connectioned between variables could be described as follows:

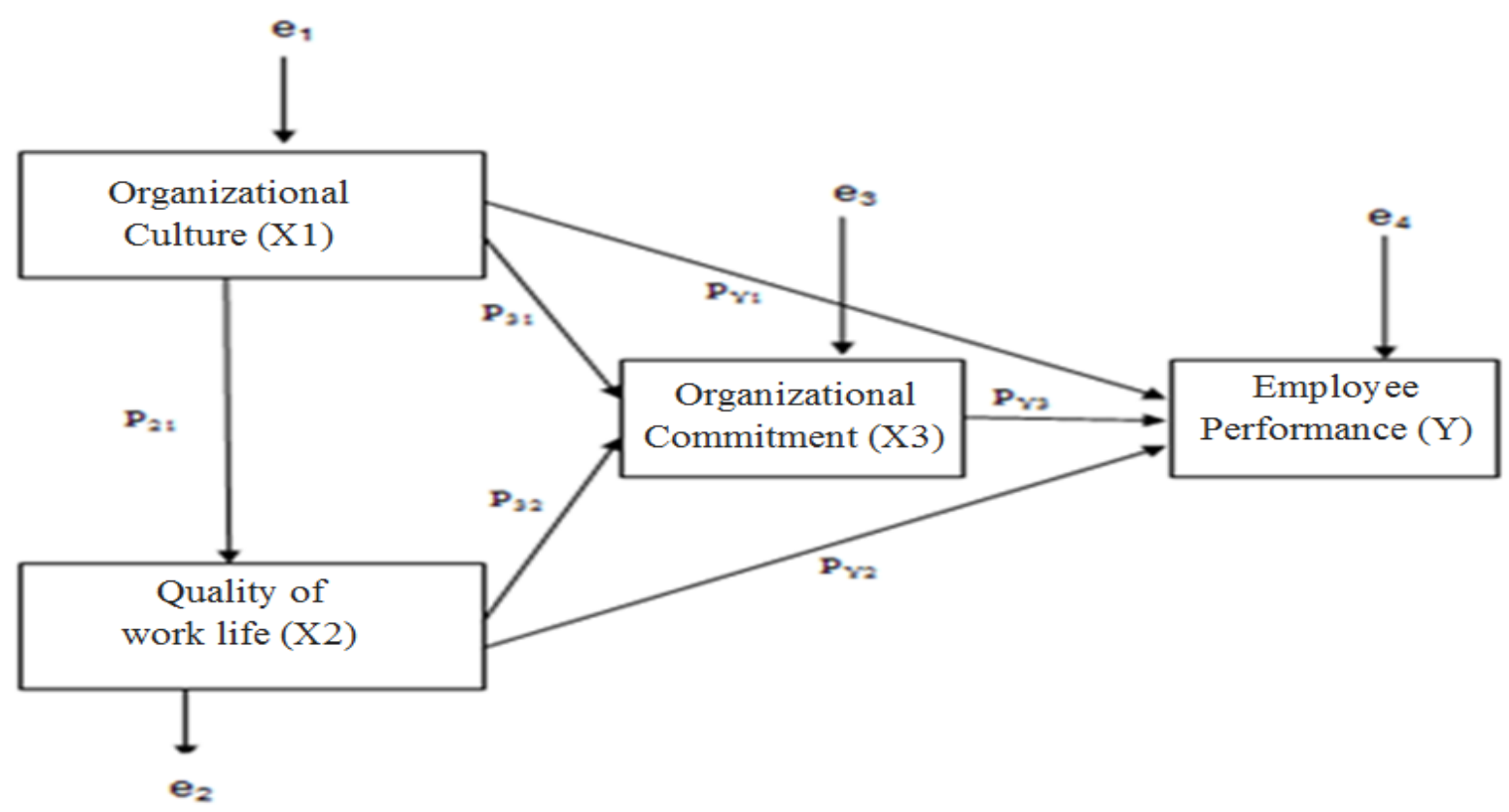

Figure 1.Causal Relationship between Variables $\left(\mathbf{X}_{1}\right),\left(\mathbf{X}_{2}\right),\left(\mathbf{X}_{3}\right)$, and $(\mathbf{Y})$

The research sample amounted to 275 employee respondents at RSPAD Gatot Soebroto Hospital Jakarta. The research data was gathered by a questionnaire. Those research instruments used in data collection have been examined for their validity and reliability.

Related to the hypothesis test, the research data was analyzed statistically both descriptively and inferentially. Descriptively, the range, mean, median, mode, standard deviation and variance were estimated. Inferential data analysis is divided into two parts, such as: (1) analysis requirements test, and (2) hypothesis test. The analysis requirements test 
includes the error normality test and linearity test to determine the connection between exogenous and endogenous variables in all ways. The Lilliefors-test used to reveal error normality and as for examining the linearity ANOVA often used simple linear regression. Meanwhile, to assess the research hypothesis used path analysis technique.

\section{RESULT AND DISCUSSION}

The data obtained through this research were included data on the variable Employee Performance (Y), Organizational Culture $\left(\mathrm{X}_{1}\right)$, Quality of Work Life $\left(\mathrm{X}_{2}\right)$ and Organizational Commitment $\left(\mathrm{X}_{3}\right)$. The results of these descriptive analysis of the data are presented like in these following table:

Table 1. The Description of Research Data

\begin{tabular}{|l|r|r|r|r|}
\hline \multicolumn{1}{|c|}{ Description } & \multicolumn{1}{c|}{$\begin{array}{c}\text { Organization } \\
\text { Culture }\end{array}$} & $\begin{array}{c}\text { Quality of } \\
\text { Work Life }\end{array}$ & $\begin{array}{c}\text { Organization } \\
\text { Commitment }\end{array}$ & \multicolumn{1}{c|}{$\begin{array}{c}\text { Employee } \\
\text { Performance }\end{array}$} \\
\hline Mean & 105.536 & 109.569 & 120.124 & 134.161 \\
\hline Standard Error & 1.007 & 1.008 & 0.999 & 0.996 \\
\hline Median & 106 & 110 & 121 & 136 \\
\hline Mode & 85 & 92 & 131 & 143 \\
\hline Standard Deviation & 16.676 & 16.687 & 16.533 & 16.494 \\
\hline Sample Variance & 278.081 & 278.444 & 273.340 & 272.047 \\
\hline Kurtosis & -1.132 & -1.149 & -0.926 & -0.576 \\
\hline Skewness & 0.098 & 0.127 & 0.115 & 0.065 \\
\hline Range & 76 & 75 & 73 & 79 \\
\hline Minimum & 69 & 75 & 89 & 96 \\
\hline Maximum & 145 & 150 & 162 & 175 \\
\hline Sum & 28.917 & 30.022 & 32.914 & 36.760 \\
\hline Count & $\mathbf{2 7 5}$ & $\mathbf{2 7 5}$ & $\mathbf{2 7 5}$ & $\mathbf{2 7 5}$ \\
\hline
\end{tabular}

Based on the normality test of the estimated error data distribution between regressions, the Asymp value obtained. Sig. (2-tailed) which is equal to $0.410>$ alpha significance level 0.05. It could be concluded that the distribution of the Estimated error data between normally distributed variables and cannot be rejected. The results of inferential data analysis related to hypothesis test are described as follows:

\section{Path Coefficients Variable $X_{1}$ to $Y\left(P_{y 1}\right), X_{2}$ ke $Y\left(P_{y 2}\right)$, and $X_{3}$ to $Y\left(P_{y 3}\right)$}

The estimation which carried out in this research was the calculation of path coefficient which related to the first, second, and third hypothesis test, namely the path coefficient between $\mathrm{X}_{1}$ to $\mathrm{Y}, \mathrm{X}_{2}$ to $\mathrm{Y}$ and $\mathrm{X}_{3}$ to $\mathrm{Y}$. The result from this calculation was presented in these following table. 
Table 2.Calculation Results of Structural Path Coefficients 1

\begin{tabular}{|c|c|c|c|c|c|c|}
\hline & \multirow[t]{2}{*}{ Model } & \multicolumn{2}{|c|}{$\begin{array}{l}\text { Unstandardized } \\
\text { Coefficients }\end{array}$} & \multirow{2}{*}{$\begin{array}{c}\text { Standardized } \\
\text { Coefficients } \\
\text { Beta }\end{array}$} & \multirow[t]{2}{*}{$\mathrm{t}$} & \multirow[t]{2}{*}{ Sig. } \\
\hline & & B & Std. Error & & & \\
\hline \multirow{4}{*}{1} & (Constant) & 31.082 & 4.031 & & 7.710 & .000 \\
\hline & $\mathrm{X}_{1}$ & .736 & .041 & .736 & 17.960 & .000 \\
\hline & $\mathrm{X}_{2}$ & .206 & .086 & .572 & 2.398 & .017 \\
\hline & $\mathrm{X}_{3}$ & .697 & .077 & .686 & 9.001 & .000 \\
\hline
\end{tabular}

According to the coefficients table above, the following values which obtained as follows:

a) $\mathrm{P}_{\mathrm{Y} 1}=0.736$, to $=17.960 ; \mathrm{t}_{\text {table }}=1.650$.

b) $\mathrm{P}_{\mathrm{Y} 2}=0.572 ;$ to $=2.938 ; \mathrm{t}_{\text {table }}=1.650$.

c) $\mathrm{P}_{\mathrm{Y} 3}=0.686 ;$ to $=9.001 ; \mathrm{t}_{\text {table }}=1.650$.

Path Coefficients Variables $X_{1}$ to $X_{3}\left(P_{31}\right)$ and $X_{2}$ to $X_{3}\left(P_{32}\right)$

This calculation which carried out in this research was the calculation of path coefficient associated with the fourth and fifth hypotheses test, namely the path coefficient between $X_{1}$ to $X_{3}$ and $X_{2}$ to $X_{3}$. The result from this calculation results are presented in these following table;

Table 3. Calculation Result of Structure Path Coefficient 2

\begin{tabular}{|c|c|c|c|c|c|c|}
\hline & \multirow[t]{2}{*}{ Model } & \multicolumn{2}{|c|}{$\begin{array}{l}\text { Unstandardized } \\
\text { Coefficients }\end{array}$} & \multirow{2}{*}{$\begin{array}{c}\text { Standardized } \\
\text { Coefficients } \\
\text { Beta }\end{array}$} & \multirow[t]{2}{*}{$\mathrm{t}$} & \multirow[t]{2}{*}{ Sig. } \\
\hline & & B & Std. Error & & & \\
\hline \multirow{3}{*}{1} & (Constant) & 18.236 & 2.955 & & 6.171 & .000 \\
\hline & $\mathrm{X}_{1}$ & .312 & .053 & .317 & 5.850 & .000 \\
\hline & $\mathrm{X}_{2}$ & .626 & .055 & .613 & 11.312 & .000 \\
\hline
\end{tabular}

Based on these coefficients table, these following value are obtained as follows:

a) $\mathrm{P}_{31}=0.317$, to $=5.850 ; \mathrm{t}_{\text {table }}=1.650$.

b) $\mathrm{P}_{32}=0.613$, to $=11.312 ; \mathrm{t}_{\text {table }}=1.650$.

\section{Path Coefficient Variables $\mathrm{X}_{1}$ to $\mathrm{X}_{2}\left(\mathrm{P}_{21}\right)$}

The calculation which carried out in this research was the calculation of the path coefficient related to the sixth hypothesis test, such as the path coefficient between $\mathrm{X}_{1}$ and $\mathrm{X}_{2}$. The summary of these calculation results was presented like in this following table: 
Table 4. The Calculation Results of Structural Path Coefficients 3

\begin{tabular}{|c|c|c|c|c|c|c|}
\hline & & Unst & dardized & Standardized & & \\
\hline & Model & $\mathrm{Co}$ & icients & Coefficients & $\mathrm{t}$ & Sig. \\
\hline & & B & Std. Error & Beta & & \\
\hline 1 & (Constant) & 2.976 & 3.348 & & .889 & .375 \\
\hline 1 & $\mathrm{X}_{1}$ & .912 & .030 & .341 & 30.850 & .000 \\
\hline
\end{tabular}

From these coefficients table, it is obtained that the price of $\mathrm{P} 21=0.341$; to $=30,469$, $t_{\text {table }}=1,650$.

The path structural model results from these calculation for Organizational Culture $\left(\mathrm{X}_{1}\right)$, Quality of Work Life $\left(\mathrm{X}_{2}\right)$ and Organizational Commitment $\left(\mathrm{X}_{3}\right)$ (exogenous variables) on Performance $(\mathrm{Y})$ is as shown as below:

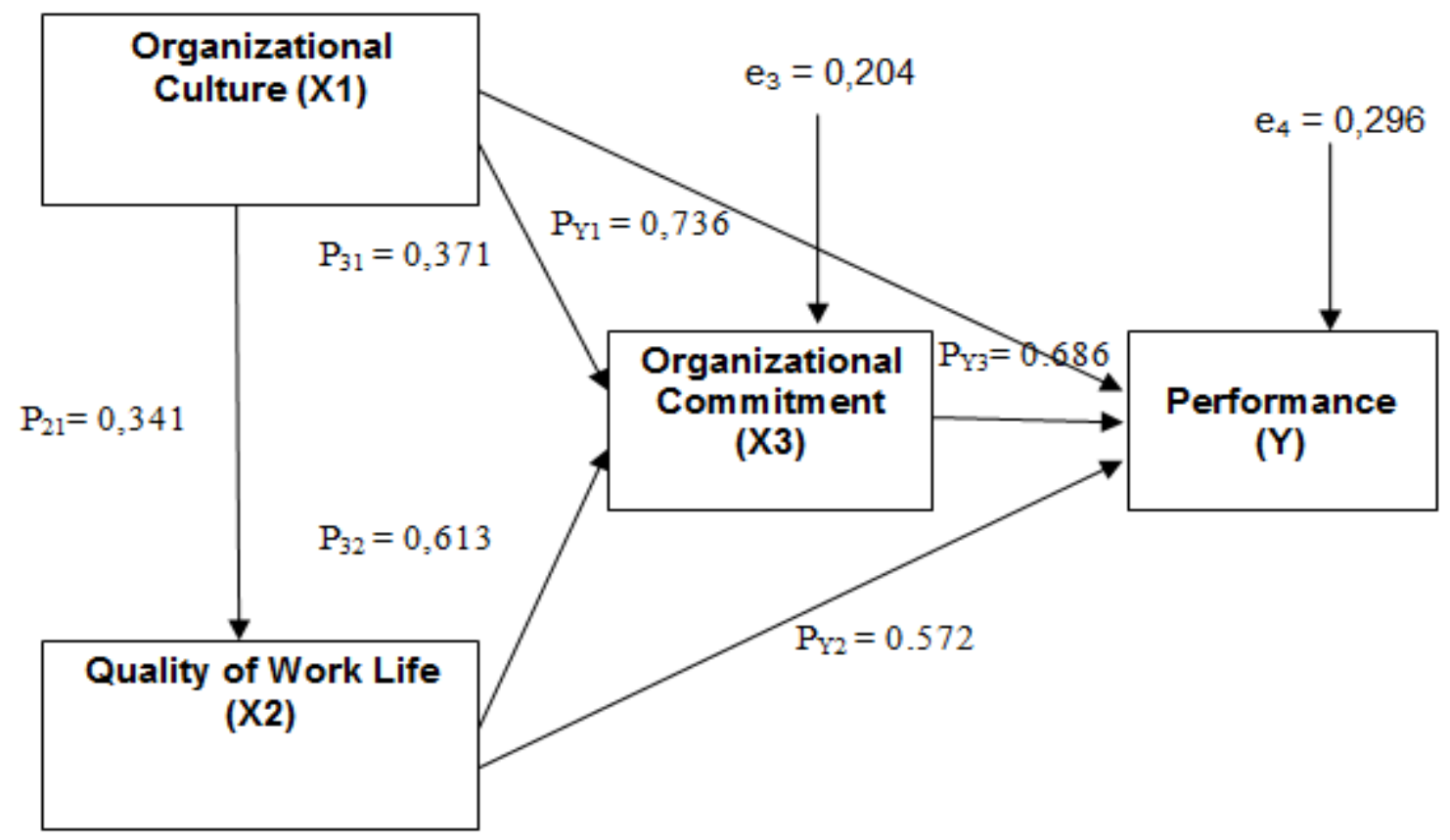

Figure 2. Form and Path Coefficient Values

\section{Hypothesis Test Results}

Based on these calculations results and statistical analysis described in the previous pages, the hypothesis test in this research could be conducted as follows:

1) The Influence of Organizational Culture $\left(\mathrm{X}_{1}\right)$ on Employee Performance (Y)

The first hypothesis stated if the organizational culture has a positive and direct impact on employee performance. Based on these calculation results it obtained the value of $\mathrm{P}_{\mathrm{y} 1}=0.736$, to $=17.960$. If we compare to $=17.960$ with $\mathrm{t}_{\text {table }}=1.650$, then to $=17.960$ was bigger than $\mathrm{t}_{\text {table }}=1.650$. Because to $=17.960>\mathrm{t}_{\text {table }}=1.650$ means that $\mathrm{H}_{0}$ was rejected or $\mathrm{H}_{1}$ was accepted. Thus, organizational culture $(\mathrm{X} 1)$ has positive and direct influence on Performance.

2) The Influence of Quality of Work Life $\left(\mathrm{X}_{2}\right)$ on Employee Performance (Y) 
The second hypothesis stated if the quality of work life $\left(\mathrm{X}_{2}\right)$ has a positive direct impact on performance $(\mathrm{Y})$. Based on these calculation results were obtained the value of $\mathrm{P}_{\mathrm{y} 2}=0.572$, to $=2.398$. If we compare to $=2.398$ with $\mathrm{t}_{\text {table }}=1.650$, then to $=2.398$ was greater than $\mathrm{t}_{\text {table }}=1.650$. Because to $=2.398>\mathrm{t}_{\text {table }}=1.650$ means that $\mathrm{H}_{0}$ was rejected or $\mathrm{H}_{1}$ was accepted. Thus the quality of work life $\left(\mathrm{X}_{2}\right)$ has a positive direct influence on employee performance (Y).

3) The Influence of Organizational Commitment $\left(\mathrm{X}_{3}\right)$ on Employee Performance $(\mathrm{Y})$

The third hypothesis stated that organizational commitment has a direct impact on employee performance. According to these calculation results obtained the value of $\mathrm{P}_{\mathrm{y} 3}=0.686$, to $=9.001$. If we compared to $=9.001$ with $\mathrm{t}_{\text {table }}=1.650$, then to $=9.001$ was greater than $\mathrm{t}_{\text {table }}=1.650$. Because to $=9.001>\mathrm{t}_{\text {table }}=1.650$ means if the $\mathrm{H}_{0}$ was rejected or $\mathrm{H}_{1}$ was accepted. Thus organizational commitment $\left(\mathrm{X}_{3}\right)$ has a positive direct influence on employee performance (Y).

4) The Influence of Organizational Culture $\left(X_{1}\right)$ on Organizational Commitment $\left(X_{3}\right)$

The fourth hypothesis stated that organizational culture has a positive direct influence on organizational commitment. Based on these calculation results, the value obtained for $\mathrm{P}_{31}=0.317$, to $=5.850$. If we compare to $=5.850$ with $\mathrm{t}_{\text {table }}=1.650$, then to $=5.850$ was bigger than $\mathrm{t}_{\text {table }}=1.650$. Because to $=5.850>\mathrm{t}_{\text {table }}=1.650$ means that $\mathrm{H}_{0}$ was rejected or $\mathrm{H}_{1}$ was accepted. Thus organizational culture $\left(\mathrm{X}_{1}\right)$ has a positive direct influence on organizational commitment $\left(\mathrm{X}_{3}\right)$.

5) The Influence of Quality of Work Life $\left(\mathrm{X}_{2}\right)$ on Organizational Commitment $\left(\mathrm{X}_{3}\right)$

The fifth hypothesis stated that the quality of work life $\left(\mathrm{X}_{2}\right)$ has a direct influence on organizational commitment $\left(\mathrm{X}_{3}\right)$. Based on these calculation results, the value obtained for $\mathrm{P}_{32}=0.613$, to $=11.310$. If we compare to $=11.310$ with $\mathrm{t}_{\text {table }}=1.650$, then to $=$ 11.310 was bigger than $\mathrm{t}_{\text {table }}=1.650$. Because to $=11.310>\mathrm{t}_{\text {table }}=1.650$ means that $\mathrm{H}_{0}$ was rejected or $\mathrm{H}_{1}$ was accepted. Thus the quality of work life $\left(\mathrm{X}_{2}\right)$ has a positive direct influence on organizational commitment $\left(\mathrm{X}_{3}\right)$.

6) The Influence of Organizational Culture $\left(X_{1}\right)$ on the Quality of Work Life $\left(X_{2}\right)$

The sixth hypothesis stated as the organizational culture $\left(\mathrm{X}_{1}\right)$ has a positive direct influence on the quality of work life $\left(\mathrm{X}_{2}\right)$. According to these calculation results, the value obtained for $\mathrm{P}_{21}=0.0 .341$, to $=30.469$ obtained. If we compare to $=30.469$ with $\mathrm{t}_{\text {table }}=1.650$, then to $=30.469$ was greater than $\mathrm{t}_{\text {table }}=1.650$. Because to $=30.469>$ $\mathrm{t}_{\text {table }}=1.650$ means that $\mathrm{H}_{0}$ was rejected or $\mathrm{H}_{1}$ was accepted. Thus organizational culture $\left(\mathrm{X}_{1}\right)$ has a positive and direct influence on the quality of work life $\left(\mathrm{X}_{2}\right)$.

\section{Discussion}

Organizational culture has valid to be an important aspect of a company, because it could and did not affect employee behavior, motivation and their values. Organizational performance management systems create career paths for employees as well as groupings of people who stay with the company for a long time to create the company culture. This illustrates that companies could apply management practices such as safety and comfort of work as well as internal career development to keep the decrease in low income, and maintain their social phenomena which are based on organizational culture (values, beliefs, norms, assumptions) in organization and therefore it will create a strong organizational culture. 
As stated by Hofstede (2011:3) that "culture is the collective programming of the mind that distinguishes the members of one group or category of people from others". Based on his statements, this is always a series of phenomena collectively, but it could be related to different collective phenomena. Culture had experiences a shift like a bell curve when a person moves from one society to another. Therefore, the culture could be said as a program that is always moving and differentiating between one group to another. This perspective leads to a cultural rotation and performance which could be interpreted as moving simultaneously.

Performance describes how far these individuals could achieve the goals that are consistent with organizational goals. Performance is also a comparison between work results with certain standards or measures such as targets, goals or criteria which have been determined and agreed upon mutually. Employee performance leads more to the level of employee performance. Mathis and Jackson defined if performance is actually the employees do and don't. Employee performance is which affects how much they contribute to the organization, including: quantity of output, quality of output, duration of output, attendance at work and cooperative attitude.

Thus the quality of work life paradigm focuses on issues such as motivation, employee involvement and job satisfaction. In general, the quality of work life tried step by step, cultivating in employees a sense of security, fairness, pride, family democracy, ownership, autonomy, responsibility and flexibility.

As stated by Muindy (2015:225) that the quality of work life has become an important part of the organization in the last 2 (two) decades due to the increasing demands of today's business environment. Quality of work life is an advantage over the conditions and environment in the workplace by supporting and promoting employee satisfaction by providing job security and rewards. The quality of work life is a shared perception and felt by members of the organization. Quality of work life means getting good supervision, good working conditions, good welfare and an interesting, challenging and rewarding job.

Regarding the employee welfare, it is not only seen by how much the employee receives a salary per month because civil servants have a salary system that is regulated by the government in accordance with applicable regulations. However, each employee has their own assumptions about the salary they received, some people think it is enough and some think it is still insufficient. Therefore, an increase in welfare in the form of providing complete work facilities and creating a quality of work life would increase peace and comfort of employees at work so the employees would gained motivation to work more productively.

Organizational commitment is a situation where an individual take sides on the organization, its goals and desires to maintain its membership in the organization. Organizational commitment towards the organization means more than just formal membership, because it includes an attitude of liking the organization and willingness to exert a high level of effort to gained the benefit for the organization and for the achievement of goals. Based on this definition, organizational commitment includes elements of loyalty to the organization, involvement in work and identification of the values and goals of the organization.

Low organizational commitment reflects a person's lack of responsibility in carrying out their duties. Talking about commitment has similiar as talking about responsibility, thus the measure of an employee's organizational commitment could be seen from (1) emotional attachment, (2) trust in the organization and (3) conformity with the organization. In this 
concept, the employees are faced with commitment to do whole things which is their duty and responsibility, in the sense that employees need to have organizational commitment to improve self-competence. By having a high competence, the quality of performance will also be high. This is in line with the statement expressed by Robbins \& Judge (2013:75) meaning that organizational commitment is the level to which an employee identifies with a particular organization and its goals and wishes to maintain membership in the organization".

Based on the description above, it could be said if this positive organizational culture could be applied in hospital organizations by internalizing these cultural values to all hospital employees maximally in order to improve employee performance. Therefore, organizational culture needs to be developed in such a way in hospital organizations, especially for employees so their performance would be more optimal. If so, the hospital culture should be strengthened and managed as an empowerment strategy for improving employee performance in order to achieve the goals set by the organization effectively and efficiently.

Institutions should aware to the details of employee needs in order to create a quality work life for employees. The demand for high quality work by the company is also followed by the fulfillment of employees' needs. Meeting the needs of employees is what causes employees to have high performance. Every employee should have an organizational commitment, it could be seen from the point which is continuously improving process capabilities, carrying out continuous improvement activities in design, work processes, products, services and reducing costs in order to increase competitiveness against the competitors which will ultimately improve the performance quality.

\section{CONCLUSION}

Based on test results of the research hypothesis, several conclusions could be made as follows: (1) Organizational culture has a positive direct influence on performance; (2) The quality of work life has a positive direct influence on employee performance; (3) Organizational commitment has a positive direct influence on employee performance;

(4) Organizational culture has a positive direct influence on organizational commitment;

(5) The quality of work life has a positive direct influence on organizational commitment;

(6) Organizational culture has a direct influence on the quality of work life. So, it is expected that RSPAD Gatot Subroto Hospital would practically re-evaluate the performance by improving the quality of performance and the factors related to organizational culture, quality of life of employees and commitment and all instruments on it. Therefore, the organizational targets could be achieved according to the work program which could determine the success of the hospital.

\section{REFERENCES}

Alvesson, M. (2013). Understanding Organizational Culture, $2^{\text {nd }}$ edition. London: Sage Publication Ltd.

Amstrong, M., \& Taylor, S. (2014). Handbook of Human Resources Management Practice, $13^{\text {th }}$ edition. London: Kogan Page.

Donnelly, J., Gibson, J. L., \& Ivancevich, J. (2012). Organization: Behaviour, Structure Processes, $14^{\text {th }}$ Edition. The McGraw-Hill Companies. 
Greet, H. (2011). Dimensionalizing Cultures: The Hofstede Model In Conte., Online Reading In Psychology and Culture, 2 (1), 2011.

Griffin, R.W., \& Moorhead, G. (2014). Organizational Behavior Managing People and Organizations, $11^{\text {st }}$ edition. South-Western.

Hall, M. (2013). Shaping Organizational Culture: A Practitioner's Perspective. Peak Development Consulting, LLC.

Hunt, O., \& Uhl-Ben. (2014). Organizational Behaviour, 13rd edition. Wiley.

Judge, T., \& Robbins, S.P. (2013). Organizational behavior. New Jersey: Pearson Education Inc.

Luthans, F. (2011). Organizational behavior, 12 th edition. Boston: McGraw-Hil.

McShane \& Glinow. (2010). Organizational Behavior. New York: McGraw-Hill.

Meyer, M. (2010). Employee Commitment and Well-Being: A Critical Review, Theoritical Framework and Research Agenda. Journal of Vacational Behavior, 77.

Muindy, P. (2015). Quality of Work,Personality, Job Satisfaction,Competence and Job Performance: A Critical Review of Literature. European Scientific Journal, 11.

Schen, E. (2010). Organizational Culture and Leadership. San Fransisco: John Wiley \& Son.

Schermerhorn, Jr., John R. Hunt, James G., \& Osborn, Richard N. (2010). Organizational Behavior. New Jersey: John Wiley and Sons, Inc.

Wayne, M., \& Martocchio, J. (2016). Human Resources Management, $14^{\text {th }}$ edition. Pearson Education Limited. 